\title{
INFLUENCE OF ROOTSTOCK ON THE MINERAL CONCENTRATIONS OF FLOWERS AND LEAVES FROM SWEET CHERRY
}

\author{
J. A. Betrán*, J. Val**, L. Montañés Millán**, E. Monge**21, L. Montañés** and M. A. Moreno** \\ * Laboratorio Agroambiental (Diputación General de Aragón), Apdo 727, 50080 Zaragoza SPAIN \\ ** Estación Experimental de Aula Dei (Consejo Superior de Investigaciones Científicas), Apartado \\ 202, 50080 Zaragoza, SPAIN
}

\begin{abstract}
The influence of rootstock on the mineral composition of scion leaves of fruit trees is generally accepted. The present work was carried out to corroborate if this influence is also evident for the mineral nutrient concentrations in flowers. The study was made in an experimental orchard of sweet cherry (Prunus avium, L. cv. 'Van') grafted on three rootstocks: Adara, SL 64 and Cok. Flowers and leaves were sampled at full bloom and 60 days after fuil bloom (DAFB) respectively. They were analyzed for nitrogen $(\mathrm{N})$, phosphorus $(\mathrm{P})$, potassium $(\mathrm{K})$, calcium $(\mathrm{Ca})$, magnesium $(\mathrm{Mg})$, sodium $(\mathrm{Na})$, iron $(\mathrm{Fe})$, manganese $(\mathrm{Mn})$, zinc $(\mathrm{Zn})$, and copper $(\mathrm{Cu})$.

Floral analysis showed that most nutrients were affected by the rootstock. P and Ca, contents behaved similarly for cherry flower and leaf $60 \mathrm{DAFB}$. The range of variation of $\mathrm{K}, \mathrm{Mg}$, and $\mathrm{Cu}$ in flowers, among rootstocks, was shorter than that of leaves. In contrast, the range of variation of $\mathrm{Na}$, $\mathrm{Zn}$, and especially Fe, in flowers was longer than that of leaves.
\end{abstract}

\section{Keywords:}

Cherry, rootstocks, flower analysis, leaf analysis, Prunus avium L., 'Van’ cv. 


\section{Introduction:}

It is commonly accepted the influence of rootstock on the mineral nutrient uptake by fruit trees and so in the foliar composition of the grafted cultivars (Boyhan et al., 1995; Knowles et al., 1984; Moreno et al., 1990; Sharma and Chauhan, 1991; Tagliavini et al., 1992; Wheaton et al., 1995). This influence has been more recently demonstrated for sweet cherry, not only referred to the mineral composition of leaves but also to the effects of the stock on fruit size and yield (Facteau et al., 1996; Moreno et al., 1996; Neilsen and Kappel, 1996).

On the other hand, Sanz and Montañés (1995b), propose the use of floral analysis as an alternative to asses the tree nutritional status, as well as a prognosis tool for iron chlorosis for peach tree (Sanz and Montañés, 1995a). For this reason, it could be of interest to consider this hypothesis for other fruit species, as cherries.

In this study, we aimed to explore if mineral composition of flowers is affected by rootstocks. Flower analytical data are also compared with those obtained for leaves taken at 60 DAFB.

\section{Material and Methods:}

The study was carried out in a 13 years oid sweet cherry orchard planted on calcareous (30\% total carbonates and $11 \%$ active lime), alkaline (pH 8.0) and clay-loam textured soil at the Estación Experimental de Aula Dei (NE Spain). The orchard was subjected to the usual cultural practices including flood irrigation. 'Van' sweet cherry cultivar was grafted on 3 different rootstocks: Adara (P cerasifera L.), SL 64 (P. mahaleb) and Colt (P. avium x P pseudocerasus). Trees were planted as a randomized complete-block design with six single tree replications per rootstock.

Whole flowers without the stalk (200 per tree) were sampled in 1995, 21 ${ }^{\circ}, 23 v^{\prime}$ and $24^{\prime}$ March for SL-64, Adara and Colt trees according to their respective full bloom dates. The samples were collcctcd from the central part of the shoots around the canopy. The samples were washed by immersion three times in deionized water, before drying ( $60^{\circ} \mathrm{C}$ into air forced stove) and grinding (in a conventional coffee mill).

From the central part of bearing shoots, fifty leaves per tree were also collected on 25" May (approximately 60 DAFB), i.e. one week before harvest maturity. The standard sampling time for cherry foliar diagnosis is usually assessed at mid summer. However, at this time, most of cherry cultivars have been already harvested. In addition, a good correlation between 60 DAFB and the values at the standard sampling time has been reported for other species (Montañés and Sanz, 1994).

Leaves were soaked in a phosphates free detergent solution (1\%), later in tap water and finally, in deionized water (three times). The petioles were separated and the leaf blades dried and milled as for the flower samples.

Flower and leaf samples were digested in a microwave furnace (HNO3 and 11202) in high pressure tefion vessels (Milestione 1.200). Analyses were performed by a colorimetric method for $P$ (phospho-vanadate reaction), Atomic Emission Spectrometry for $\mathrm{K}$ and $\mathrm{Na}$, and Atomic Absorption Spectrometry (Perkin-Elmer 1.100) for ca, Mg, Fe, Mn, Zn and cu. Nitrogen was determined by Kjeldhai. Each determination was replicated three times. The results were expressed on a dry matter basis: \% for macro and mg kg for microelements.

The data were evaluated by analysis of variance and means were separated by Duncan's test when the $\mathrm{F}$ test was significant. 


\section{Results and Discussion:}

In general, minera! element concentration in flowers at full bloom and leaves (60 DAFB) were significantly influenced by rootstock (Table 1 ).

\subsection{Flowers composition}

Concentrations of $\mathrm{N}$ and $\mathrm{Mn}$ in flowers were significantly greater when grafted on Adara or colt. P concentration was greater on SL 64, lower on Colt, and intermediate on Adara, although the iatter did not differ from the other two rootstocks. The ca concentration was higher on colt, lower on Adara and intermediate on SL64, being the last not different from the other two rootstocks. Na and Zn concentrations were higher on Adara, lower on SL 64 and intermediate, but not significantly different from the other two stocks, on colt.

The floral Fe concentration the sole element that in flowers was significantly different on the three rootstocks. It was higher on SL 64, intermediate on Adara and lower on Colt. Floral Fe concentration on Colt was reduced by $25 \%$ and $40 \%$ compared to Adara and SL 64, respectively. Since colt rootstock appears less suitable for calcareous soils than SL 64 and Adara (Bononad et al., 1988; Moreno et al., 1996), the floral mineral analysis could reveal a relationship between this behavior and a lower Fe concentration. Since the leaf Fe concentrations of Fe deficient trees appear to be similar to those of Fe sufficient trees (Abadía, 1992), the mineral analysis of flowers might be used to carry out the prognosis of Fe deficiency in cherry trees.

By contrast, the $\mathrm{Cu}, \mathrm{K}$ and $\mathrm{Mg}$ concentrations of flowers were lot significant among rootstocks. In particular, the behaviour of $\mathrm{Cu}$ can be considered normal if we take unto account its low concentration, as well as the narrow range of its variation among the three rootstocks experimented.

According to these findings, the analysis of flowers could also be used as a tool to evaluate the adaptability of rootstocks to some particular growing conditions. Therefore, as an approach for measuring the nutrient uptake capacity as influenced by the rootstock. However, new researches will be necessary to confirm this assert.

\subsection{Comparison between flowers and leaves (60 DAFB)}

In previous works (Sanz et al 1992; Montañés and Sanz, 1994), the foliar analysis at 60 DAFB was proposed as an early sampling time for foliar diagnosis in peach tree. This date was also found valuable to show the different nutritional behaviour of some rootstocks for sweet cherry (Moreno et al., 1996).

As before mentioned, the mineral concentration of flowers and leaves at 60 DAFB have demonstrated, in this study, the influence of rootstock on the mineral nutrition of cherry trees (Table 1).

Rootstock had no effect on leaf $\mathrm{Na}$, Fe and Zn concentration. By contrast, flower analysis revealed differences among rootstocks for these nutrients, especially for Fe concentration. As previously reported for pear (Sanz et al., 1994) and peach (Sanz and Montañés, 1995), the range of variation of Fe concentration in flowers was greater than that of leaves. 
Table 1. Rootstock effects on flower (Flw) and leaf (Lf) at 60 DAFB mineral concentrations of 'Van' sweet cherry. Results for N, P, K, Mg and Ca are expressed as percentage of dry matter and for $\mathrm{Na}, \mathrm{Fe}, \mathrm{Mn}, \mathrm{Cu}$ and $\mathrm{Zn}$, as $\mathrm{mg} \mathrm{kg}$.

Mean separation in columns by Duncan's multiple range test at $\mathrm{P}<0.05$.

Means followed by the same letter within a column for a rootstock are lot significantly different.

\begin{tabular}{l|cc|cc|cc|cc|cc|}
\multicolumn{3}{|c}{$\mathbf{N}$} & \multicolumn{2}{c}{ P } & \multicolumn{2}{c}{ K } & \multicolumn{2}{c}{ Mg } & \multicolumn{2}{c|}{ Ca } \\
& Flw & Lf & Flw & Lf & Flw & Lf & Flw & Lf & Flw & Lf \\
\cline { 2 - 11 } Adara & $3.51 \mathrm{~b}$ & $2.49 \mathrm{~b}$ & $0.52 \mathrm{ab}$ & $0.32 \mathrm{ab}$ & $3.01 \mathrm{a}$ & $2.61 \mathrm{c}$ & $0.25 \mathrm{a}$ & $0.39 \mathrm{a}$ & $0.45 \mathrm{a}$ & $2.26 \mathrm{a}$ \\
SL 64 & $3.15 \mathrm{a}$ & $2.37 \mathrm{~b}$ & $0.53 \mathrm{~b}$ & $0.35 \mathrm{~b}$ & $3.01 \mathrm{a}$ & $1.94 \mathrm{~b}$ & $0.27 \mathrm{a}$ & $0.57 \mathrm{~b}$ & $0.49 \mathrm{ab}$ & $2.98 \mathrm{~b}$ \\
Colt & $3.40 \mathrm{~b}$ & $2.02 \mathrm{a}$ & $0.50 \mathrm{a}$ & $0.27 \mathrm{a}$ & $3.05 \mathrm{a}$ & $1.43 \mathrm{a}$ & $0.24 \mathrm{a}$ & $0.75 \mathrm{c}$ & $0.59 \mathrm{~b}$ & $4.24 \mathrm{c}$
\end{tabular}

\begin{tabular}{l|cc|cc|cc|cc|cc|}
\multicolumn{3}{c}{} & \multicolumn{2}{c}{ Na } & \multicolumn{2}{c}{ Fe } & \multicolumn{2}{c}{ Mn } & \multicolumn{2}{c}{ Zn } \\
& Flw & Lf & Flw & Lf & Flw & Lf & Flw & Lf & Flw & Lf \\
\cline { 2 - 10 } Adara & $141 \mathrm{~b}$ & $96 \mathrm{a}$ & $122 \mathrm{~b}$ & $73 \mathrm{a}$ & $12 \mathrm{a}$ & $8 \mathrm{~b}$ & $27 \mathrm{~b}$ & $49 \mathrm{~b}$ & $53 \mathrm{~b}$ & $18 \mathrm{a}$ \\
SL 64 & $103 \mathrm{a}$ & $108 \mathrm{a}$ & $152 \mathrm{c}$ & $72 \mathrm{a}$ & $13 \mathrm{a}$ & $8 \mathrm{~b}$ & $19 \mathrm{a}$ & $37 \mathrm{a}$ & $42 \mathrm{a}$ & $22 \mathrm{a}$ \\
Colt & $120 \mathrm{ab}$ & $144 \mathrm{a}$ & $92 \mathrm{a}$ & $68 \mathrm{a}$ & $11 \mathrm{a}$ & $7 \mathrm{a}$ & $27 \mathrm{~b}$ & $38 \mathrm{a}$ & $50 \mathrm{ab}$ & $24 \mathrm{a}$
\end{tabular}

\section{Acknowledgements:}

The authors thank M. Grao and P. Casabón for their skillful technical contribution in the mineral analysis, carried out at the Laboratorio Agroambiental (Diputación General de Aragón). This work was supported by research grants PCA-4/91 and PCA-6/91 CONAI (Diputación General de Aragón), and Comisión Interministerial de Ciencia y Tecnología projects AGR 91-0434 and AGF94- 1030-003-01.

\section{References:}

Abadía, J., 1992. Leaf responses to Fe deficiency: a review. J. Plant Nutr. 15, 1699-1713.

Bononad, S.; De Andrés, T.; Díez, B.; Espada, J. L.; Reinoso, D. y Cambra, R. 1988. Comportamiento del patrón de cerezo 'Colt', en algunas localidades españolas.ITEA, 77: 43-50.

Boyhan, G. E., Norton, J. D., and Pitts, J. A. 1995. Establishment, growth, and foliar nutrient content of plum trees on various rootstocks. HortScience 30(2): 219-221.

Facteau, T. J., Chesnut, N. E. and Rowe, K. E. 1996. Tree, fruit size and yield of 'Bing' sweet cherry as influenced by rootstock, replant area, and training system. Sci. Hort. 67: 13-26.

Knowles, J. W., Dozier, W. A., Evans, C. E., Cariton, C. C. and McGuire, J. M. 1984. Peach rootstock influence on foliar and dormant stem nutrient content. J. Amer. Soc. Hort. Sci. 109: 440444.

Montañés, L. and Sanz, M. 1994. Prediction of reference values for early leaf analysis for peach trees. J. Plant Nutr. 17 (10): 1647-1657. 
Moreno, M. A., Montañés, L., Sanz, M., and Tabuenca, M. C. 1990. Comportamiento y estado nutricional de la variedad de melocotonero vesuvio sobre diversos patrones. Actas del III Symposium Nacional de Nutrición Mineral de Plantas: Nutrición mineral bajo condiciones de estrés: Palma de Mallorca, Spain. pp. 137-142.

Moreno, M. A., Montañés, L., Tabuenca, M. C., and Cambra, R. 1996. The performance of Adara as a cherry rootstock. Sci. Hortic. 65: 85-91.

Neilsen, G. and Kappel, F. 1996. 'Bing' Sweet cherry leaf nutrition is affected by rootstock. HortScience 31: 1169-1172.

Sanz, M., Heras, L. and Montañés, L., 1992. Relationships between yield and leaf nutrient contents in peach trees: early nutritional status diagnosis. J. Plant Nutr. 15: 1457- 1466.

Sanz, M., Carrera, M. and Montañés, L. 1994. The possibility of using floral analysis to diagnose the nutritional status of pear trees. Acta Horticulturae 367: 290-295.

Sanz, M. and Montañés, L. 1995a. Floral analysis: A novel approach for the prognosis of iron deficiency in pear (Pyrus communis, L.) and peach (Prunus persica L., Batsch). In: J. Abadía (ed.) Iron nutrition in soils and plants: 371-374. Kluwer Academic Publishers. The Netherlands.

Sanz, M., and Montañés, L., 1995b. Flower analysis as a new approach to diagnosing the nutritional status of the peach tree. J. Plant Nutr. 18: 1667-1675.

Sharma, D. D. and Chauhan, J. S. 1991. Effects of different rootstocks and training systems on the mineral compostion of 'Delicious' apple leaves. J. Hort Sci. 66: 703-707.

Tagliavini, M., Scudellari, D., Marangoni, B., Bastianel, A., Franzin, F. and Zamborini, M. 1992. Leaf mineral composition of apple tree: sampling date and effects of cultivar and rootstock. 1. Plant Nutr. 15: 605-619.

Wheaton, T. A., Whitney, J. D., Casstle, W. S., Muraro, R. P., Browing, H. W. and Tucker, D. P. H. 1995. Citrus scion and rootstock, topping height, and tree spacing affect tree size, yield, fruit quality, and economic return. J. Amer. Soc. Hort. 120: 86 1-870. 